point, it does not necessarily follow that this is genetically determined. Members of a family tend to share the same environment, and any characteristic occurring in certain families may therefore be the result of acquired rather than congenital disease. Whatever the cause of migraine this communitybased family survey suggests that heredity is less important than is usually supposed.

I thank Professor A. L. Cochrane, Dr. J. A. Fraser Roberts, and Dr. J. O. Robinson for advice and help with these epidemiological studies. I thank members of the M.R.C. Epidemiology Unit (South Wales) for all their work and the Migraine Trust for a grant to aid this research.

Aring, C. D. (1962). American Heart fournal, 64, 715.

Balyeat, R. M., and Rinkel, H. J. (1931). Annals of Internal Medicine, 5, 713. Barolin, G. S. (1970). In Background to Migraine, ed. A. L. Cochrane, p. 28. London, Heinemann

Bille, B. (1962). Acta Paediatrica, 51, Suppl. No. 136.

Blau, J. N. (1969). Bombay Hospital fournal, 11, 1.

Callaghan, N. (1968). Neurology (Minneapolis), 18, 197.
Childs, A. J., and Sweetnam, M. T. (1961). British fournal of Industrial Medicine, 18, 234.

Dalsgaard-Nielsen, T. (1965). Acta Neurologica Scandinavica, 41, 287.

Fothergill, J. (1784). Medical Observations and Enquiries, 6, 103.

General Register Office (1966). Classification of Occupations. London, H.M.S.O.

Grimes, E. (1931). Medical fournal and Record, 134, 417.

Heim, A. W. (1967). AH4 Group Test of General Intelligence: Manual. Slough, National Foundation for Educational Research.

Lennox, W. G. (1941). Science and Seizures. New York, Harper.

Leyton, N. (1954). Migraine and Periodic Headache. London, Heinemann.

Liveing, E. (1873). On Megrim, Sick-headache, and Some Allied Disorders. London, Churchill.

Pratt, R. (1967). Genetics of Neurological Disorders, p. 122. London, University Press. Selby, G., and Lance, J. W. (1960). Fournal of Neurology, Neurosurgery and
Psychiatry, 23, 23.

Selinsky, H. (1939). Bulletin of the New York Academy of Medicine, 15, 757. Simpson, J. A. (1968). In Textbook of Medical Treatment, ed. D. Dunlop. Edinburgh, Livingstone.

Walker, C. H. (1959). British Medical fournal, 2, 1430.

Waters, W. E. (1970a). Lancet, 2, 1 .

Waters, W. E. (1970a). Lancet, 2, 1. 178

Waters, W. E. (1970b). Headache, 9, 178.

Waters, W. E., and O'Connor, P. J. (1970). In Background to Migraine: Third Migraine Symposium, ed. A. L. Cochrane, p. 1. London, Heinemann.

Weinberg, W. (1931). Archiv für Rassen- und Gesellschaft-Biologie, 23, 275.

Wolf, H. G. (1963). Headache and Other Head Pain. New York, Oxford University Press.

\title{
Further Observations on the Relation between Iron and Folate Status in Pregnancy
}

\author{
I. CHANARIN, DOREEN ROTHMAN
}

British Medical fournal, 1971, 2, 81-84

\section{Summary}

This study was planned to determine whether iron deficiency in pregnancy predisposed to the development of folate deficiency and also the smallest daily iron supplement that maintained haemoglobin levels in pregnancy.

Three groups of women were given oral ferrous fumarate supplying 30, 60, and $120 \mathrm{mg}$ of iron; a fourth group was given $1 \mathrm{~g}$ of parenteral iron in early pregnancy followed by oral iron $(60 \mathrm{mg})$; a fifth group received a placebo. Tablets were taken once daily.

Oral iron $30 \mathrm{mg}$ once daily maintained haemoglobin levels throughout pregnancy. Women whose marrows lacked demonstrable iron at the 37th week had a significantly higher incidence of megaloblastic haemopoiesis $(28.7 \%)$ than those with demonstrable iron stores (15.3\%); women taking oral iron did not have a lower frequency of megaloblastosis than those given a placebo. We concluded that iron does not have a direct effect on folate status in pregnancy, that the association of iron deficiency and megaloblastic anaemia in pregnancy is the result of poor nutrition, and that there is no cause-andeffect relation between them.

\section{St. Mary's Hospital, London W.2}

I. CHANARIN, M.D., M.R.C.PATH., Consultant Haematologist (Present address: Department of Haematology, Northwick Park Hospital, Watford Road, Harrow, Middlesex HAl 3UJ)

DOREEN ROTHMAN, B.SC., M.R.C.o.g., Lecturer in Obstetrics and Gynaecology (Present address : c/o Department of Health, Alexander Fleming House, Elephant and Castle, London S.E.1)

\section{Introduction}

Women who are iron deficient throughout pregnancy are sometimes said to be more likely to become folate deficient as well. Thus it was reported that in pregnancy iron-deficient women were more likely to have an excess of hypersegmented neutrophils in blood films, lower serum folate levels, and megaloblastic haemopoiesis in marrow films than pregnant women who had received ample iron (Chanarin, Rothman, and Berry, 1965). A higher frequency of megaloblastic anaemia in pregnancy in the iron-deficient group was reported by Lowenstein, Brunton, and Hsieh (1966) and by Willoughby (1967). Similar findings were reported in iron-deficient infants by Vossough, Leikin, and Purugganan (1968).

Some further supportive evidence has come from the responses of patients to iron therapy. Gross, Keefer, and Newman (1965) reported the disappearance of an abnormal excretion of formiminoglutamic acid in infants with both iron deficiency and megaloblastic haemopoiesis given iron alone, and Velez, Restreppo, Bustamente, and Vitale (1965) reported the disappearance of megaloblastic marrow change on iron therapy in patients with iron deficiency due to hookworm infestation, coupled with malnutrition.

Abnormalities in folate metabolism such as reduced levels of formiminotransferase enzyme in iron-depleted rats were noted by Vitale, Streiff, and Hellerstein (1965) and Vitale, Restreppo, Velez, Riker, and Hellerstein (1966) but not by Burns and Spray (1969).

There are varying explanations for some of these observations relating iron and folate status. It could well be that some workers are reading too much into minor variations in marrow morphology. Even where iron and folate deficiency coexist both could be due to underlying nutritional causes and not have any cause-and-effect relation. The topic is of particular importance in pregnancy, when iron and folate deficiency 
are trequent, and after gastrectomy, when iron and vitamin$\mathrm{B}_{12}$ deficiency may coexist.

The purpose of this study was twofold: to obtain further information about the relation between iron deficiency and megaloblastic haemopoiesis in pregnancy, and to determine the smallest iron supplement required to maintain haemoglobin levels throughout pregnancy when taken once daily.

\section{Patients and Methods}

Patients booking into the antenatal clinic at St. Mary's Hospital before the 20th week of pregnancy were approached and the nature of the study was explained to them. If agreeable they were allocated in sequence to one of five groups. One of these groups was given $1 \mathrm{~g}$ of iron (Imferon, $4 \times 250 \mathrm{mg}$ ) intravenously before the 20 th week and thereafter ferrous fumarate $(60 \mathrm{mg}$ of elemental iron once daily) throughout pregnancy. The other four groups were given either a placebo or one of three oral doses of iron to be taken once daily. The amount of iron as ferrous fumarate was 30,60 , and $120 \mathrm{mg}$. With the exception of the tablets given to the group who had received parenteral iron the content of the prescribed tablets was not known to us during the study.

A full blood count and a serum iron estimation was carried out on the first visit and at the 20th, 25th, 30th, and 37th week of pregnancy. A sternal marrow aspiration was carried out on all patients at the 37 th week. After allowance had been made for subjects dropping out of the study, usually because they left the district, there were just under 50 subjects in each group. Eleven had to be given more energetic iron therapy for anaemia. Nine of these were derived from the group given the placebo and two from the groups taking doses of 30 and 120 mg. In these a marrow aspiration was done at the time they were withdrawn from the survey. In 11 patients it was either not possible to obtain a marrow or the aspiration failed to yield adequate material.

Sternal marrow results were all assessed together at the end of the survey. None of the patients was known to the observer assessing the marrow, nor was there any indication to which group they had been assigned. Marrows were assessed for the presence of stainable iron in films stained by Perls's method and for the presence of megaloblastic haemopoiesis in films stained by the May-Grünwald-Giemsa stain.

\section{Results}

Amount of Iron Required to Maintain Haemoglobin Levels.The mean haemoglobin, packed cell volume, and serum iron levels were essentially the same in all groups receiving iron and was significantly lower only after the 30th week in the placebo group (Table I). Thus the group given only $30 \mathrm{mg}$ of elemental iron a day did as well as the group receiving intravenous and oral dosage.

Frequency of Megaloblastosis.-Of 240 marrows examined, $62(25.8 \%)$ showed early megaloblastic haemopoiesis (Table II). Of 188 marrows without any stainable iron $54(28.7 \%)$

TABLE II-Frequency of Megaloblastic Haemopoiesis in Marrow Aspirates

\begin{tabular}{|c|c|c|c|}
\hline & & $\begin{array}{c}\text { Marrow Iron } \\
\text { Present at } 37 \text { Weeks }\end{array}$ & $\begin{array}{l}\text { No Stainable } \\
\text { Marrow Iron }\end{array}$ \\
\hline $\begin{array}{l}\text { Total No. } \\
\text { No. megaloblastic }\end{array}$ & $\begin{array}{l}\cdots \\
\cdots\end{array}$ & $\begin{aligned} & 52(22 \%) \\
& 8(15 \cdot 3 \%)\end{aligned}$ & $\begin{array}{r}188(78 \%) \\
54(28 \cdot 7 \%)\end{array}$ \\
\hline
\end{tabular}

were megaloblastic. Stainable iron was present in 52 marrows $(22 \%)$ and $8(15.3 \%)$ of these were megaloblastic. The difference in frequency of megaloblastosis in relation to marrow iron stores was significant at the $5 \%$ level. When the patients were grouped in relation to the serum iron level

TABLE III-Relationship between Serum Iron and Megaloblastosis

\begin{tabular}{|c|c|c|c|c|c|c|}
\hline \multirow{2}{*}{\multicolumn{2}{|c|}{ Week of Pregnancy }} & & & \multicolumn{3}{|c|}{ Serum Iron $(\mu \mathrm{g} / 100 \mathrm{ml})$} \\
\hline & & & & $>60$ & $40-60$ & $<40$ \\
\hline $\begin{array}{l}20 \\
30 \\
37\end{array}$ & $\begin{array}{l}\cdots \\
\cdots\end{array}$ & $\begin{array}{l}\ldots \\
\cdots\end{array}$ & $\begin{array}{l}\ldots \\
\cdots\end{array}$ & $\begin{array}{l}22.0 \% \\
30.7 \% \\
31.4 \%\end{array}$ & $\begin{array}{l}24.7 \% \\
21.0 \% \\
24.9 \%\end{array}$ & $\begin{array}{l}25 \cdot 0 \% \\
28.0 \% \\
15 \cdot 4 \%\end{array}$ \\
\hline
\end{tabular}

*Percentage of patients who were found to be megaloblastic at 37 weeks.

(Table III) the frequency of megaloblastosis was $15.4 \%$ in those with serum iron levels below $40 \mu \mathrm{g} / 100 \mathrm{ml}$ at the $37 \mathrm{th}$ week, $24.9 \%$ in those with serum iron levels of 40 to $60 \mu \mathrm{g}$, and $31.4 \%$ in those with serum levels above $60 \mu \mathrm{g}$. No such relation was evident at 20 or 30 weeks of pregnancy.

TABLE IV-Birth Weight and Marrow Findings

\begin{tabular}{|c|c|c|c|c|c|c|c|}
\hline \multirow{3}{*}{ Mother } & \multirow{3}{*}{ Infant } & \multicolumn{3}{|c|}{ Megaloblastic } & \multicolumn{3}{|c|}{ Normoblastic } \\
\hline & & \multirow{2}{*}{ No. } & Birth & Weight (kg) & \multirow{2}{*}{ No. } & \multicolumn{2}{|c|}{ Birth Weight (kg) } \\
\hline & & & Mean & Range & & Mean & Range \\
\hline $\begin{array}{l}\text { Primiparae } \\
\text { Multiparae }\end{array}$ & $\begin{array}{l}\text { Male } \\
\text { Female } \\
\text { Male } \\
\text { Female }\end{array}$ & $\begin{array}{l}12 \\
17 \\
16 \\
14\end{array}$ & $\begin{array}{l}3.38 \\
3.33 \\
3.59 \\
3.39\end{array}$ & $\begin{array}{l}2 \cdot 69-4 \cdot 39 \\
2 \cdot 57-4 \cdot 22 \\
2 \cdot 47-4 \cdot 28 \\
2 \cdot 92-4 \cdot 05\end{array}$ & $\begin{array}{l}61 \\
50 \\
33 \\
18\end{array}$ & $\begin{array}{l}3 \cdot 34 \\
3 \cdot 24 \\
3 \cdot 54 \\
3 \cdot 35\end{array}$ & $\begin{array}{l}2 \cdot 41-4 \cdot 45 \\
2 \cdot 27-4 \cdot 02 \\
2 \cdot 18-5 \cdot 45 \\
2 \cdot 55-3 \cdot 88\end{array}$ \\
\hline
\end{tabular}

TABLE I-Mean Haemoglobin, P.C.V., and Serum Iron Throughout Pregnancy, the Frequency of Megaloblastic Marrow Changes and the Presence of Marrow Iron (Perls's Method) at the 37 th Week of Pregnancy

\begin{tabular}{|c|c|c|c|c|c|c|c|c|c|c|c|c|c|c|c|c|c|c|c|c|c|}
\hline & & & & & & & & & & Duratic & $n$ of $\operatorname{Pr}$ & gnancy & weeks) & & & & & & 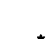 & A & \\
\hline & & & & & & & 20 & & & 25 & & & 30 & & & 37 & & & row * & $\mathrm{p}$ & \\
\hline & $\begin{array}{r}\mathrm{Dai} \\
\mathrm{S} \\
(\mathrm{mg} \mathrm{E}\end{array}$ & $\begin{array}{l}\text { Ora } \\
\text { plem }\end{array}$ & $\begin{array}{l}\text { ron } \\
\text { It } \\
\text { Iron) }\end{array}$ & & No. & 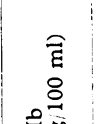 & $\frac{3}{\dot{c}}$ & 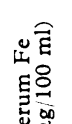 & 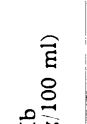 & $\frac{\partial}{3}$ & 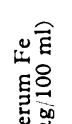 & 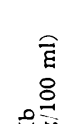 & 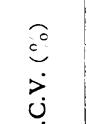 & 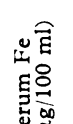 & $\begin{array}{r}\text { ह } \\
8 \\
\end{array}$ & $\frac{20}{\stackrel{0}{0}}$ & 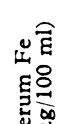 & $\begin{array}{l}\text { Meg } \\
\text { blas }\end{array}$ & & & $\begin{array}{l}\text { nce } \\
\text { able } \\
\text { n }\end{array}$ \\
\hline & & & & & & & $G$ & & & G & & & ai & & & C & & No. & $\%$ & No. & $\%$ \\
\hline 0 & . & . & . & . & 46 & $\begin{array}{c}11.9 \\
+0.11+\end{array}$ & $\begin{array}{r}36 \cdot 1 \\
+0.33\end{array}$ & $\begin{array}{l}65 \\
\pm 3.1\end{array}$ & $\begin{array}{c}11.5 \\
+0.11\end{array}$ & $\begin{array}{c}35 \cdot 4 \\
+0 \cdot 32\end{array}$ & $\begin{array}{c}54 \\
+3.4\end{array}$ & $\begin{array}{c}11.5 \\
\pm 0.14\end{array}$ & $\begin{array}{c}34.8 \\
+0.40\end{array}$ & $\begin{array}{c}50 \\
+3.4\end{array}$ & $\begin{array}{c}11.4 \\
+0.14\end{array}$ & $\begin{array}{c}35.2 \\
\pm 0.40\end{array}$ & $\begin{array}{c}36 \\
+2 \cdot 2\end{array}$ & 5 & 11 & 1 & 2 \\
\hline $0+\mathrm{I}$. & V. Fe & r 3 & veeks & .. & 11 & $\begin{array}{c}10.8 \\
10.18 \\
+0.18\end{array}$ & $\begin{array}{r}+0.33 \\
33.5 \\
+0.61\end{array}$ & $\begin{array}{r}57 \\
57 \\
+\quad 8.0\end{array}$ & $\begin{array}{r}9.9 \\
+0.24\end{array}$ & $\begin{array}{r}31.3 \\
+0.63\end{array}$ & $\begin{array}{r}39 \\
+6.6\end{array}$ & $\begin{array}{r}9.8 \\
+0.23\end{array}$ & $\begin{array}{c}30.9 \\
+0.64\end{array}$ & $\begin{array}{r}34 \\
+6.9\end{array}$ & $\begin{array}{c}10 \cdot 0 \\
+0.38\end{array}$ & $\begin{array}{r}31.6 \\
+0.73\end{array}$ & $\begin{array}{r}30 \\
+7 \cdot 3\end{array}$ & $2 \ddagger$ & 18 & 0 & 0 \\
\hline 30 & $\ldots$ & .. & . & $\ldots$ & 49 & $\begin{array}{c}11.8 \\
\pm 0.10\end{array}$ & $\begin{array}{r}36.3 \\
+0.29\end{array}$ & $\begin{array}{r}66 \\
+3.5\end{array}$ & $\begin{array}{l}11.6 \\
+0.11\end{array}$ & $\begin{array}{l}35.7 \\
+0.35\end{array}$ & $\begin{array}{r}64 \\
+3.2\end{array}$ & $\begin{array}{r}11.9 \\
+0.12\end{array}$ & $\begin{array}{c}36.0 \\
+0.35\end{array}$ & $\begin{array}{r}63 \\
+42\end{array}$ & $\begin{array}{r}12.4 \\
+0.14\end{array}$ & $\begin{array}{r}37.7 \\
+0.39\end{array}$ & $\begin{array}{r}67 \\
+4.3\end{array}$ & 15 & 32 & 9 & 19 \\
\hline 60 & .. & .. & .. & .. & 47 & $\begin{array}{c}11.7 \\
+0.12\end{array}$ & $\begin{array}{l}35.7 \\
+0.35\end{array}$ & $\begin{array}{r}62 \\
+3.2\end{array}$ & $\begin{array}{r}11.5 \\
+0.12\end{array}$ & $\begin{array}{r}35.4 \\
+0.31\end{array}$ & $\begin{array}{r}58 \\
+3.8\end{array}$ & $\begin{array}{r}11.6 \\
+0.12\end{array}$ & $\begin{array}{r}35.5 \\
-0.32\end{array}$ & $\begin{array}{r}57.9 \\
+3.6\end{array}$ & $\begin{array}{r}12.1 \\
+0.16\end{array}$ & $\begin{array}{r}37.1 \\
+0.45\end{array}$ & $\begin{array}{r}60 \\
+3.2\end{array}$ & 10 & 24 & 4 & 10 \\
\hline 120 & . & . & .. & $\ldots$ & 49 & \begin{tabular}{c}
11.6 \\
11.6 \\
\hdashline 0.12
\end{tabular} & $\begin{array}{l}35.4 \\
+0.35\end{array}$ & $\begin{array}{r}62 \\
\quad 2.9\end{array}$ & $\begin{array}{r}11.4 \\
+0.26\end{array}$ & $\begin{array}{r}35.6 \\
-0.38\end{array}$ & $\begin{array}{r}60 \\
+2.9\end{array}$ & $\begin{array}{r}11.6 \\
10.13\end{array}$ & $\begin{array}{r}35.7 \\
+0.38\end{array}$ & 62 & $\begin{array}{r}12.2 \\
+0.26\end{array}$ & $\begin{array}{r}37.9 \\
+0.46\end{array}$ & $\begin{array}{r}68 \\
+3.7\end{array}$ & 18 & 37 & 14 & 29 \\
\hline $60+1$ & $1 \mathrm{~g} \mathrm{I} . \mathrm{V}$. & 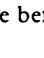 & $20 \mathrm{w}$ & eeks & 49 & $\begin{array}{c}11.5 \\
\pm 0.13\end{array}$ & $\begin{array}{l}35 \cdot 4 \\
10.35\end{array}$ & $\begin{array}{l}67 \\
\therefore \quad 3 \cdot 2\end{array}$ & $\begin{array}{c}11.5 \\
\pm 0.12\end{array}$ & $\begin{array}{l}35.4 \\
\pm 0.36\end{array}$ & $\begin{array}{r}61 \\
+2.7\end{array}$ & $\begin{array}{l}11.6 \\
\pm 0.14\end{array}$ & $\begin{array}{c}35 \cdot 7 \\
\pm 0.39\end{array}$ & $\begin{array}{l}60 \\
\pm 3.7\end{array}$ & $\begin{array}{c}12 \cdot 2 \\
\pm 0.14\end{array}$ & $\begin{array}{l}37.5 \\
\pm 0.40\end{array}$ & $\begin{array}{r}57 \\
+2.8\end{array}$ & 10 & 22 & 22 & 49 \\
\hline
\end{tabular}


Clinical Findings.-The incidence of obstetric complications was determined on 238 patients: 62 showed early megaloblastic erythropoiesis on bone marrow examination and 176 had normoblastic marrows. The number of complications in the series was small, as would be expected from this number of patients. There was no apparent increase in antepartum haemorrhage, threatened abortion, urinary tract infection, fetal abnormality, pregnancy hypertension, premature delivery, and puerpural infection in those patients with megaloblastic anaemia.

Birth Weight.-The birth weight of 221 babies was analysed (all single pregnancies). These were all over 38 weeks' gestation at the time of delivery. They were subdivided in relation to sex and parity of the mother. There was no significant difference in the birth weights of the babies of patients with megaloblastic changes in the bone marrow and those with normoblastic marrows. There was, however, a slightly higher birth weight in all four groups of babies of the megaloblastic mothers of the order of $50 \mathrm{~g}$ and a lower birth weight in those with haemoglobin levels below $10 \mathrm{~g}$. These differences were not significant (Table IV).

\section{Discussion}

\section{MINIMUM EFFECTIVE DAILY IRON SUPPLEMENT}

The least amount of iron given to our subjects was $30 \mathrm{mg}$ of elemental iron as a single daily dose, and this proved effective in maintaining haemoglobin levels throughout pregnancy. It should be added that all the women were carefully supervised at the antenatal clinic, only one monthly supply of tablets was given, and the bottle was brought back at the end of the month. Thus there is every reason to believe that the bulk of the prescribed tablets were taken by most of the subjects.

There are few studies which provide information about the smallest dose of iron effective in maintaining haemoglobin levels in pregnancy, and, indeed, a recent W.H.O. publication suggested the need for a study wherein zero, 20, 60, and 120 $\mathrm{mg}$ of iron per day were given in pregnancy. de Leeuw, Lowenstein, and Hsieh (1966) found that $39 \mathrm{mg}$ of iron was not effective, but that $78 \mathrm{mg}$ of iron daily did maintain haemoglobin levels. Our data do not support this finding, and a possible explanation could be failure of the Montreal subjects to take their tablets. Iyengar and Apte (1970) showed that most pregnant women given $30 \mathrm{mg}$ of iron daily maintained their haemoglobin levels.

\section{RELATION BETWEEN IRON AND FOLATE}

There was an overall relation between the presence or absence of stainable marrow iron and the incidence of megaloblastic haemopoiesis-that is, those without demonstrable marrow iron showed megaloblastic haemopoiesis twice as often as did those with iron. This difference was significant.

The random allocation of subjects to five groups should have ensured that the folate and iron status of the subjects in these groups was essentially the same. Administration of iron in adequate amounts, as assessed by maintenance of haemoglobin and serum iron levels, to the subjects in four of these groups should have left folate supply as the only determinant in the production of a megaloblastic form of haemopoiesis. The subjects given a placebo would be expected to have the same folate status, but, as indicated in the fall in the serum iron level and reduced haemoglobin level, they also manifested iron deficiency. If lack of iron aggravated folate status a higher frequency of megaloblastosis should have appeared in this group. This was not the case. Indeed this group manifested the lowest frequency of megaloblastosis possibly because the morphological changes were concealed by a predominant iron deficiency. Thus the conclusion of this study is that iron deficiency did not have a direct effect on folate status, as judged by the frequency of megaloblastosis, and that the explanation for the overall association between iron deficiency and megaloblastic anaemia shown in this study as well as by Chanarin et al. (1965), Lowenstein et al. (1966), and Willoughby (1967) is that both these states are a manifestation of malnutrition. A diet deficient in folate is also likely to be deficient in iron, and hence the manifestation of both deficiencies are likely to appear in the same patients. This explanation was first put forward by Lowenstein et al. (1966).

Nutritional folate status in early pregnancy is an important factor in determining whether megaloblastic anaemia will develop, and both Chanarin, Rothman, Ward, and Perry (1968) and Temperley, Meehan, and Gatenby (1968) found that subjects who became megaloblastic had low red cell folate levels and low serum folate levels respectively in the early weeks of pregnancy. Equally, their iron status at this time too determines whether they can pass through pregnancy without developing anaemia. Where both iron and folate are deficient, anaemia due to lack of both factors tends to appear.

It was difficult to forecast possible relations between serum iron levels and the frequency of megaloblastosis. If iron deficiency predisposed to folate deficiency then the highest frequency of megaloblastic change might be expected to occur in those with the lowest serum iron levels. On the other hand, megaloblastic change itself leads to a rise in serum iron levels so that the group with the highest frequency of megaloblastic anaemia should have the highest serum iron levels. The latter possibility proved to be correct-that is, there were twice as many women with megaloblastic change in the group with serum iron levels above $60 \mu \mathrm{g} / 100 \mathrm{ml}$ as in the group with serum iron levels below $40 \mu \mathrm{g} / 100 \mathrm{ml}$.

\section{BIRTH WEIGHT}

There was a slightly higher birth weight in all four groups of babies of the megaloblastic mothers of the order of $50 \mathrm{~g}$. Where folate deficiency is severe it may be responsible for prematurity and low birth weight, and this is prevented by folate supplementation (Baumslag, Edelstein, and Metz, 1970). On the other hand, anaemia in the population we studied is due to iron deficiency, and folate status is generally adequate. Under these circumstances a large baby may produce a larger folate requirement and this may provide an explanation for the larger babies in the megaloblastic group-that is, these pregnancies required more folate to meet the increased demand of the bigger fetus. Similar results were obtained by us in a previous study (Chanarin et al., 1968).

There was some suggestion that birth weight was reduced in the anaemic patients (haemoglobin less than $10 \mathrm{~g}$ ). The numbers were too small for these figures to be significant but the data are in keeping with the suggestion that the anaemic group is a nutritionally deprived group.

We are grateful to support from Glaxo Laboratories. We also wish to acknowledge our indebtedness to Mr. Michael Healy for help with the statistics. 


\section{References}

Baumslag, N., Edelstein, T., and Metz, J. (1970). British Medical fournal, 1,16 .

1, 16. G., and Spray, G. H. (1969). British fournal of Nutrition, 23, 665.

Chanarin, I., Rothman, D., and Berry, V. (1965). British Medical fournal, $1,480$.

Chanarin, I., Rothman, D., Ward, A., and Perry, J. (1968). British Medical Fournal, 2, 390.

de Leeuw, N. K. M., Lowenstein, L., and Hsieh, Y.-S. (1966). Medicine, $45,291$.

Gross, S., Keefer, V., and Newman, A. J. (1965). Lancet, 2, 744.

Iyengar, L., and Apte, S. V. (1970). American fournal of Clinical Nutrition,
Lowenstein, L., Brunton, L., and Hsieh, Y.-S. (1966). Canadian Medical Association fournal, 94, 636.

Temperley, I. J., Meehan, M. J. M., and Gatenby, P. B. B. (1968). British Fournal of Haematology, 14, 13.

Velez, H., Restreppo, A., Bustamente, J., and Vitale, J. J. (1965). American fournal of Clinical Nutrition, 16, 383.

Vitale, J. J., Restreppo, A., Velez, H., Riker, J. B., and Hellerstein, E. E. (1966). Fournal of Nutrition, 88, 315 .

Vitale, J. J., Streiff, R. R., and Hellerstein, E. E. (1965). Lancet, 2, 393.

Vossough, P., Leikin, S., and Purugganan, G. (1968). Pediatric Research, 2

Willoughby, M. L. N. (1967). British fournal of Haematology, 13, 503.

\title{
Diabetes after Removal of Insulin Tumours of Pancreas: A Long-term Follow-up Survey of 11 Patients
}

\author{
D. C. DUNN
}

British Medical fournal, 1971, 2, 84-87

\section{Summary}

Eleven patients who had islet cell tumours of the pancreas removed over a 20-year period were reviewed. Two had died, one in the postoperative period and one 10 years postoperatively. The remaining nine were traced and eight of them were personally interviewed and tested. All nine were well and free from recurrent symptoms. Five of the eight had evidence of subnormal insulin production in response to oral glucose. Glucose tolerance was impaired in three. Minor anomalies were found in the electroencephalograms of all these patients and major abnormalities in two.

The results of this survey suggest that other patients who have had islet cell tumours removed may now have unsuspected diabetes.

\section{Introduction}

Though it is 40 years since the association of islet cell tumours of the pancreas with clinical hypoglycaemia was established, little is known about the patients who have had tumours removed. Follow-up information is mainly limited to whether they have had recurrent hypoglycaemic attacks or have remained well.

\section{Subjects and Methods}

Since 194711 patients have had islet cell tumours excised at St. Bartholomew's Hospital. These were reviewed and those living were traced. Eight were personally interviewed and examined. Information was obtained from one patient by letter. The period of follow-up ranged from six months to 18 years, five patients having survived over 10 years. The operations carried out are listed in the Table.
St. Bartholomew's Hospital, London E.C.1

D. C. DUNN, F.R.C.s., Senior House Officer (Present address: Addenbrooke's Hospital, Cambridge CB2 2AH)
At follow-up the facts of each recorded case history were checked with the patient. Where possible the relatives and general practitioners were questioned about the patient's past and present mental health. Over a period of three hours a glucose tolerance test (using $50 \mathrm{~g}$ of glucose dissolved in water taken orally) was performed; serum samples were taken for insulin levels; and electroencephalograms were recorded at different blood sugar levels. The serum calcium was also measured.

Blood glucose was measured by AutoAnalyzer. The method was a modification of the Technicon ferricyanide reduction method, which has given results very close to a glucoseoxidase method. Serum insulins were measured by an immunoassay method using the Amersham kit based on the method of Hales and Randle (1963). Control values for the insulin and glucose levels, supplied by the laboratories carrying out the estimations, are shown in Figs. 1 and 2. The electroencephalograms were interpreted by Dr. J. $H$. Margerison.

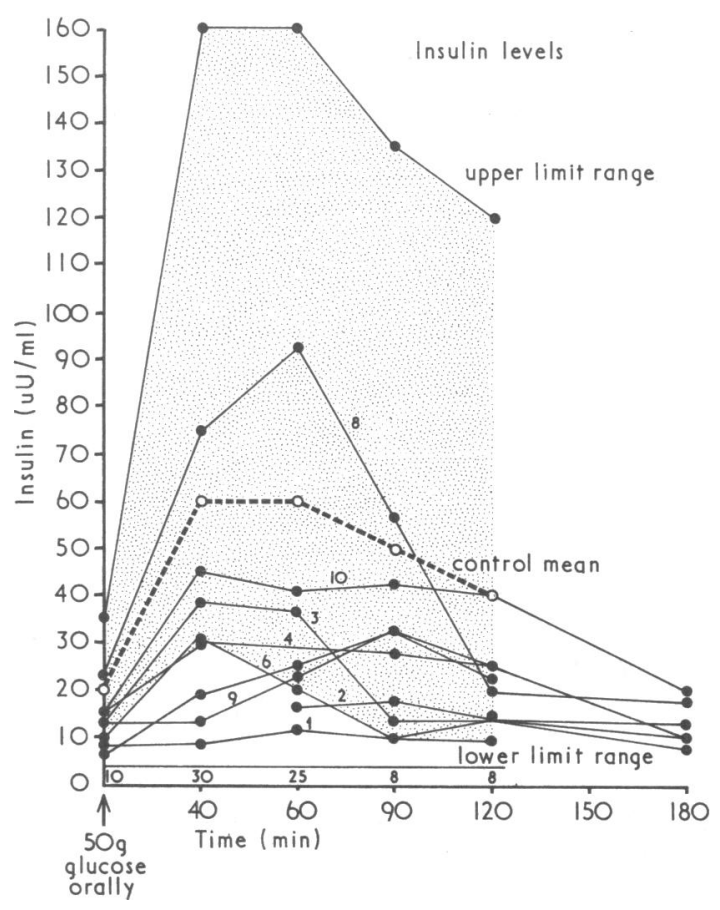

FIG 1 -Insulin responses to $50 \mathrm{~g}$ oral glucose. Numbers refer to cases listed in the Table. 